\title{
TEKNIK IDENTIFIKASI KEBUTUHAN BELAJAR BERBASIS PARTISIPASI MASYARAKAT DALAM PELATIHAN KEWIRAUSAHAAN
}

\author{
Dayat Hidayat \\ Program Studi Pendidikan Luar Sekolah, FKIP \\ Universitas Singaperbangsa Karawang - Jawa Barat - Indonesia \\ dayat.hidayat@fkip.unsika.ac.id
}

\begin{abstract}
Received: April, 2020; Accepted: Mei, 2020

The lack of success in the development of community entrepreneurship programs is due to the low participation of citizens learning in learning at PKBM Nurul Furqon. The learning community was less involved in planning the entrepreneurship training program that was carried out. This condition is the background of the management to identify community learning needs in developing entrepreneurship training programs at PKBM Nurul Furqon. This identification technique is used to increase citizen participation in learning to participate in entrepreneurship training based on community participation. The purpose of this study is to describe the technique of identifying learning needs based on community participation in entrepreneurship training at PKBM Nurul Furqon. The study was conducted using a qualitative approach and case study method. Data collection techniques using observation, interviews and documentation studies. The results of the study concluded that the objective of identifying entrepreneurship training was to obtain data on problems encountered and determine the needs of citizens to learn, formulate, plan, and carry out the entrepreneurship training process. At the end of the training process an assessment is aimed at comparing all the capital or business costs incurred with the results, benefits, and business benefits that have been obtained by the learning community.
\end{abstract}

Keywords: Identification techniques, community participation, entrepreneurship training

\begin{abstract}
Abstrak
Kurang berhasilnya pengembangan program kewirausahaan masyarakat disebabkan rendahnya partisipasi warga belajar mengikuti pembelajaran di PKBM Nurul Furqon. Warga belajar kurang dilibatkan dalam merencanakan program pelatihan kewirausahaan yang dilaksanakan. Kondisi ini yang latar belakang pengurus melakukan identifikasi kebutuhan belajar masyarakat dalam menyusun program pelatihan kewirausahaan di PKBM Nurul Furqon. Teknik identifikasi ini digunakan untuk meningkatkan partisipasi warga belajar mengikuti pelatihan kewirausahaan berbasis partisipasi masyarakat. Tujuan penelitian ini untuk mendeskripsikan teknik identifikasi kebutuhan belajar berbasis partisipasi masyarakat dalam pelatihan kewirausahaan di PKBM Nurul Furqon. Penelitian dilakukan menggunakan pendekatan kualitatif dan metode studi kasus. Teknik pengumpulan data menggunakan observasi, wawancara dan studi dokumentasi. Hasil penelitian menyimpulkan bahwa tujuan identifikasi pelatihan kewirausahaan dilakukan untuk memperoleh data permasalahan yang dihadapi dan menentukan kebutuhan warga belajar, merumuskan, menyusun perencanaan, dan melaksanakan proses pelatihan kewirausahaan. Pada akhir proses pelatihan dilakukan penilaian yang bertujuan membandingkan seluruh modal atau biaya usaha yang dikeluarkan dengan hasil, manfaat, dan keuntungan usaha yang telah diperoleh warga belajar.
\end{abstract}

Kata Kunci: Teknik identifikasi, partisipasi masyarakat, pelatihan kewirausahaan

How to Cite: Hidayat, D. (2020). Teknik Identifikasi Kebutuhan Belajar Berbasis Partisipasi Masyarakat Dalam Pelatihan Kewirausahaan. Comm-Edu (Community Education Journal) 3 (2), 156-166. 


\section{PENDAHULUAN}

Dasar pemikiran partisipasi masyarakat pada program pemberdayaan sebagian besar datang dari "atas" atau dari "luar" komunitas yang sering mengalami kegagalan karena kurang sesuai dengan yang dibutuhkan warga setempat (lokal). Pegiat pembangunan, khususnya bidang pendidikan sering mengalami frustasi karena kegagalan program pemberdayaan masyarakat. Dengan demikian, harus dilakukan reorientasi ulang dalam menentukan strategi bidang pendidikan masyarakat yang mengutamakan partisipasi masyarakat sebagai strategi pendidikan masyarakat. Untuk diperlukan strategi dan metode yang mampu menciptakan situasi, kondisi, dan proses pemberdayaan yang dapat melibatkan masyarakat secara aktif. Hakekatnya, masyarakat dan lingkungannya berpotensi baik ditinjau dari sumberdaya alam, maupun dari sumberdaya sosial dan budaya. Masyarakat memiliki 'kekuatan' yang dapat dimanfaatkan sebagai energi besar dalam pemberdayaan. Cara menggali potensi dengan mendayagunakan sumber-sumber daya di lingkungan masyarakat sebagai faktor penentu utama pemberdayaan masyarakat. Dalam proses pemberdayaan, masyarakat berperan sangat penting sebagai pelaku aktif pembangunan. Prinsip gerakan pemberdayaan masyarakat, harus mengutamakan ide, gagasan, inisiatif, inovasi, dan kreasi masyarakat, serta menggunakan strategi utama dengan memberikan kekuatan kepada masyarakat. Masyarakat dalam menentukan program pendidikan lebih diutamakan untuk memahami permasalahan dan kebutuhannya. Masyarakat sejak tahap perencanaan program pendidikan harus dilibatkan/diikutsertakan dan diberdayakan untuk mengenali kebutuhan-kebutuhannya dan menggali potensi-potensinya. Masyarakat turut merumuskan perencanaan, melaksanakan, dan menilai program pendidikan masyarakat secara mandiri dan berswadaya. Partisipasi masyarakat dalam pemberdayaan adalah konsep dan prinsip pembangunan berdemokrasi, yaitu dari, oleh, dan untuk masyarakat. Partisipasi masyarakat pada proses pembangunan bidang pendidikan harus secara bertahap ditumbuhkan, didorong dan dikembangkan sehingga ajeg dan berkesinambungan. Jiwa partisipasi masyarakat merupakan wujud semangat solidaritas modal sosial. Masyarakat melaksanakan program pendidikan memiliki hubungan sosial selalu atas dasar perasaan moral bersama, kepercayaan bersama dan cita-cita yang dibangun bersama. Karena itu, seluruh masyarakat harus dimotivasi untuk mengenali berbagai potensi yang dimilikinya, kemudian bekerja saling bahu membahu, menjaga komitmen moral dan sosial yang tinggi melaksanakan pembangunan pendidikan masyarakat. Beberapa aspek yang perlu mendapat perhatian untuk dianalisis, ditumbuhkan dan ditingkatkan dalam memasyarakatkan program pemberdayaan, seperti: perumusan konsep; penyusunan model; proses perencanaan; pelaksanaan gerakan pemberdayaan; pemantauan; pengawasan; penilaian hasil pelaksanaan; dan pengembangan gerakan pemberdayaan. Seperti hasil penelitian Hermawan, Y. dan Suryono, Y. (2016) menunjukkan bahwa tahapan partisipasi masyarakat dimulai dari proses perencanaan, pelaksanaan, evaluasi serta pemanfaatan hasil. Bentuk partisipasi masyarakat terbagi dalam dua bentuk meliputi; fisik yaitu material dan tenaga, dan nonfisik yaitu ide atau gagasan. Strategi yang digunakan dalam mengembangkan partisipasi masyarakat dilaksanakan melalui komunikasi, keterlibatan masyarakat dan memberdayakan komunitas dalam penyelenggaraan program-program di PKBM Ngudi Kapinteran, Semanu, Gunungkidul.

Program pemberdayaan untuk meningkatkan kesejahteraan ekonomi dapat dilaksanakan melalui pendidikan masyarakat dan pelatihan kewirausahaan. Pelatihan kewirausahaan dilaksanakan dengan tujuan meningkatkan kemandirian ekonomi. Pelatihan kewirausahaan banyak andilnya untuk mewujudkan kemandirian ekonomi. Banyak perumus konsep kewirausahaan, yang disetujui oleh McClelland. Pelatihan kewirausahaan sering dilakukan dengan merintis usaha kecil-kecilan masyarakat. Salah satu lembaga perintis usaha kecil yang tumbuh berkembang di masyarakat adalah Pusat Kegiatan Belajar Masyarakat (PKBM). 
Dilihat dari segi penyelenggaraannya, PKBM harus mampu mengenali, menggali, memanfaatkan, dan mendayagunakan seluruh potensi lingkungan, mampu mensosialisasikan program pendidikan dan kewirausahaan, dan mampu menjalin kerjasama serta kemitraan dengan berbagai pihak lain, untuk mendukung kegiatan kewirausahaan masyarakat. Dengan pendekatan kolaboratif dilakukan perencanaan inovatif dan kreatif yang ditandai munculnya gagasan dan komitmen baru dalam membantu memecahkan masalah kehidupan ekonomi dan sosial yang dihadapi masyarakat, seperti bidang ekonomi kerakyatan. Hal ini sejalan dengan penelitian Rosyida, I. dan Nasdian, F.T. (2011) yang memberikan gambaran bahwa program pemberdayaan ekonomi lokal melalui kelompok simpan pinjam berjalan baik karena adanya partisipasi masyarakat. Partisipasi tersebut memiliki hubungan dan berdampak secara sosial dan ekonomi bagi masyarakat Desa Cihamerang kecamatan Kabandungan Kabupaten Sukabumi. Tingkat partisipasi anggota kelompok simpan pinjam tersebut tinggi, sehingga dampak sosial dan ekonominyapun tinggi juga. Dampak sosial ekonomi yang diperoleh anggota kelompok simpan pinjam tersebut ditentukan oleh partisipasi masyarakat dan stakeholder terkait lainnya.

Dalam pelaksanaan kewirausahaan di PKBM, masyarakat perlu diberikan pelatihan. Proses pelatihan kewirausahaan dirancang mulai dari tahapan persiapan, pelaksanaan, dan penilaian. Tahap persiapan, pihak penyelenggara harus menyiapkan program menyeluruh, cermat, siap memberikan program tersebut terlaksana dengan efisien, efektif, dan berkualitas. Pada tahap pelaksanaan program, yang dirancang lebih banyak dari pada teori; semua sumber daya pendidikan yang disiapkan dengan cermat, perlu didayagunakan dengan tepat, sehingga warga belajar mendapatkan peluang untuk menghadapi langsung dan memfasilitasi dengan berbagai sumber belajar. Dengan pendampingan yang tepat setiap wargabelajar mencerna dan menyelesaikan pengalaman belajar yang mereka peroleh. Pada tahap penilaian diperoleh capaian hasil pelatihan. Pada tahap penilaian ini yang perlu dipantau adalah penguasaan wawasan, kreatifitas, dan keberanian untuk memulai dan mengembangkan usaha; dengan bekal keterampilan kejuruan yang telah dikuasai.

PKBM merupakan suatu kegiatan membelajarkan warga belajar melalui pendidikan yang menggunakan prinsip pembelajaran berbasis kebutuhan masyarakat. Pengurus PKBM Nurul Furqon Desa Pangulah Utara, melakukan perencanaan pelatihan kewirausahaan dengan melibatkan masyarakat melalui teknik identifikasi kebutuhan belajar. Teknik identifikasi tersebut digunakan mulai menyusun desain, instrumen, pengumpulan data, pengolahan, analisis data sampai menyusun laporan; selalu bersama masyarakat yang diperankan bukan sebagai objek melainkan subjek/pelaku pada proses pelatihan. Teknik identifikasi ini khas dalam kegiatan perencanaan program atau proyek yang mengendepankan peran aktif dari masyarakat dalam setiap langkah pelatihan, termasuk dari mulai memahami masalah dan potensi lokal, mengidentifikasi dan menganalisis kebutuhan belajar sampai menentukan rumusan tujuan dan penyusunan perencanaan kegiatan yang dilaksanakan, serta pendayagunaan sumber-sumber yang tersedia di sekitarnya. Hal ini sejalan dengan hasil penelitian Syahid, A. (2017) yang menyimpulkan bahwa tujuan identifikasi program Paket C berbasis kewirausahaan adalah mengumpulkan data, merumuskan, menyusun kebutuhan belajar sebagai dasar perencanaan, proses, penentuan waktu, penyediaan sarana, dan media pembelajaran di PKBM Buana Mekar Kabupaten Karawang. Teknik identifikasi menggunakan Kartu SKBM, wawancara, angket, observasi, pertemuan kelompok, dan teknik indikator sosial.

Teknik identifikasi kebutuhan belajar di PKBM Nurul Furqon merupakan tahapan penting dalam perencanaan program pelatihan kewirausahaan untuk melahirkan wirausahawanwirausahawan masyarakat baru. Teknik identifikasi ini digunakan agar warga belajar dapat 
berpartisipasi aktif dalam perumusan tujuan belajar, penyusunan desain pelatihan, pelaksanaan, dan penilaian hasil pelatihan kewirausahaan di PKBM Nurul Furqon. Kegiatan ini dilakukan karena dalam pengembangan program kewirausahaan sebelumnya kurang melibatkan partisipasi masyarakat, sehingga identifikasi dirasakan sangat perlu untuk dilakukan. Kondisi inilah yang menjadi latar belakang penelitian tentang Teknik Identifikasi Kebutuhan Pelatihan Kewirausahaan Berbasis Partisipasi Masyarakat di PKBM Nurul Furqon Desa Pangulah Utara Kecamatan Kotabaru Kabupaten Karawang.

\section{LANDASAN TEORI}

\section{Pelatihan}

Pelatihan dapat didefinisikan sebagai sejumlah proses pengajaran atau sederetan mata pelajaran yang disampaikan kepada peserta didik di dalam maupun di luar organisasi/lembaga. Pelatihan merupakan proses penguasaan pengetahuan, sikap dan keterampilan tertentu atau suatu subject matter oleh peserta didik yang menimbulkan perubahan perbuatan atau perilaku. Kegiatan pelatihan diadakan untuk memenuhi suatu kebutuhan organisasi yang secara fungsional dengan berbagai alasan seperti: struktur dan fungsi bagian-bagian ingin menyesuaikan beban dan kualitas tugasnya, sehingga personalianya memiliki kemampuan yang unggul dalam menjalankan pekerjaannya. Secara prinsip pelatihan dilaksanakan untuk memenuhi kebutuhan lembaga atau organisasi. Pelatihan merupakan suatu kegiatan pembelajaran yang bermaksud membimbing peserta didik agar menjalankan pekerjaannya pada masa sekarang atau masa depan dengan mengembangkan perilaku, kebiasaan, kecakapan, pengetahuan dan sikap tertentu yang diperlukan.

Dalam suatu organisasi/lembaga dimana ditempatkan orang-orang baru untuk suatu jabatan atau pengurus lama yang dipromosikan untuk memangku jabatan baru, perlu diberikan pelatihan khusus agar dapat melaksanakan peran, tugas dan fungsi organisasinya dengan baik. Flippo (1994) menyatakan bahwa "Training is concerned with increasing knowledge and skill in doing a particular job". Selanjutnya William B.W. Jr. dan Davis, K. (1986:282) mengemukakan bahwa: "Training help employees do their job, the benefits of training may extended throughout a person's career and help develop that person for future responsibilities". Pelatihan dilaksanakan berkaitan dengan upaya peningkatan sikap, perilaku, pengetahuan dan keterampilan tertentu dalam melakukan pekerjaannya. Pelatihan di perusahaan misalnya, dilaksanakan untuk membantu karyawan melakukan pekerjaannya. Manfaat pelatihan kerja dapat diperluas sepanjang karier seseorang dan membantu mengembangkan orang itu untuk bertanggungjawab secara baik di masa depan. Sedangkan Cascio, W.F. (1995:24) menyatakan bahwa, "Training consist of planed program designed to improve performance individual, group and/or organization level. Improved performance implies that this have measurable changes in knowledge, skill, attitudes and social behaviour". Pelatihan adalah proses pendidikan yang meliputi suatu desain program perencanaan untuk memperbaiki perilaku individu, kelompok dan atau tingkat organisasi. Peningkatan kinerja hasil pelatihan menyiratkan bahwa kondisi ini memiliki perubahan yang terukur dalam aspek pengetahuan, keterampilan, sikap dan perilaku sosial peserta didik di masyarakat.

\section{Kewirausahaan}

Di Indonesia, istilah kewirausahaan (entrepreneurship) mulai dikenal sekitar tahun tahun 1970-an. Istilah yang dipakai adalah wirausaha sebagai terjemahan dari enterpreneur, sedangkan jiwa kewirausahaan merupakan terjemahan dari enterpreneurship yang dipopulerkan oleh Sumahamijaya, S. (1980). Drucker, P.F. (1994:2) mengemukakan bahwa kewirausahaan adalah suatu kemampuan menciptakan sesuatu yang baru dan berbeda (ability 
to create the new and different). Bahkan, "entrepreneurship" secara sederhana sering juga diartikan sebagai prinsip atau kemampuan wirausaha (Ibnu Soedjono, 1993; Meredith, G., 1996; Marzuki Usman, 1997:1). Kewirausahaan adalah kemampuan mengelola, memanfaatkan, menggerakkan dan mengarahkan sumber daya tenaga kerja, berbagai alat produksi usaha dalam menciptakan produk tertentu yang dapat ditukarkan atau dijual pada situasi pasar, dan memperoleh sumber pendapatan demi kelangsungan hidupnya. Kewirausahaan merupakan suatu disiplin ilmu yang mempelajari tentang nilai, kemampuan (ability) dan perilaku seseorang dalam menghadapi tantangan hidup untuk memperoleh peluang dengan berbagai risiko yang mungkin dihadapinya. Dalam konteks bisnis, Zimmerer, T.W. (1996) mengemukakan bahwa "Entrepreneurship is the result of a disciplined, systematic process of applying creativity and innovations to need and opportunities in the market place".

Kewirausahaan merupakan proses dan hasil kedisiplinan yang sistematis dalam menerapkan kreativitas dan keinovasian dalam mengembangkan usaha dengan mencari peluang pasar untuk memenuhi kebutuhan hidupnya. Wirausahawan merupakan sikap dan perilaku yang dimiliki seseorang untuk mengkombinasikan unsur-unsur (elemen-elemen) dalam dirinya (internal) seperti; visi, motivasi, komunikasi, rasa percaya diri, optimis, semangat, dan mampu menggali dan memanfaatkan peluang usaha. Seorang wirausaha adalah sesorang yang mendirikan, mengelola, dan mengembangkan usaha serta melembagakannya dengan penuh kreatif, inovatif, swakendali, mampu mengambil resiko, mampu melihat kedepat, mampu membuka dan memanfaatkan peluang, dapat bergaul dengan baik, mampu bekerja keras, memiliki keyakinan diri dan mampu bersikap mandiri. Saat ini banyak dirintis pendidikan kewirausahaan dalam berbagai model pelatihan kerja.

Pelatihan kewirausahaan menitikberatkan kepada penempaan nilai-nilai kepribadian berwirausaha, melalui metode "pengulangan latihan" mengenai sikap mental, cara berpikir dan cara bertindak. Pelatihan kewirausahaan dilaksanakan bukan sekedar pendidikan teknik manajemen modern, karena kalau hanya mengajarkan hal-hal teknis saja tanpa disertai dengan pembinaan pribadi yang kreatif hanya akan menghasilkan manusia-manusia yang tetap malas dan tidak efisien. Karena itu pelatihan kewirausahaan dilaksanakan agar manusia memiliki kepribadian kuat, dinamis dan kreatif, sehingga memiliki motivasi kuat untuk tumbuh dan berkembang maju dan menjadi kaya lahir dan batin.

\section{Pemberdayaan Ekonomi Masyarakat}

Pemberdayaan masyarakat bertujuan untuk membantu dan meningkatkan kemampuan sosial ekonomi masyarakat, sehingga titik berat proses pembangunan masyarakat selalu mengacu pada arah terciptanya kondisi sosial ekonomi masyarakat yang terus tumbuh dan berkembang dan maju atas dasar hakekat dan prinsip-prinsip pembangunan masyarakat. Pemberdayaan ekonomi dan sosial, budaya dijadikan dasar pentingnya pembangunan masyarakat, memberikan indikasi bahwa pembangunan masyarakat, dalam prosesnya menerapkan prinsipprinsip keswadayaan. Pembangunan diarahkan untuk meningkatkan kemandirian masyarakat untuk meningkatkan kesejahteraan kehidupannya. Pemberdayaan masyarakat merujuk pada usaha pengalokasian kembali kekuasaan melalui pengubahan struktur sosial (Swift dan Levin, 1987). Rappaport. J. (1984) mengemukakan bahwa pemberdayaan adalah suatu cara dimana rakyat, organisasi, dan komunitas diarahkan agar mampu menguasai (atau berkuasa atas) kehidupannya (Suharto, E. 2004). Pemberdayaan masyarakat merupakan sebuah konsep pembangunan ekonomi yang merangkum nilai-nilai sosial. Konsep ini mencerminkan paradigma baru pembangunan, yakni yang bersifat "people centred, participatory, empowering, and sustainable" (Chambers, R., 1995). Pendidikan masyarakat menaruh 
perhatian besar pada kebutuhan masyarakat serta identifikasi kebutuhan yang dilaksanakan masyarakat itu sendiri. Pendidikan masyarakat melalui partisipasi berpendirian, bahwa penyusunan program pendidikan yang paling utama adalah bersumber pada dan bertujuan memenuhi berbagai kebutuhan belajar masyarakat tertentu.

\section{METODE PENELITIAN}

Penelitian ini menggunakan pendekatan kualitatif untuk mencari dan mendeskripsikan data dari kasus tentang identifikasi pengembangan kewirausahaan masyarakat di PKBM Nurul Furqon. Pendekatan ini menghasilkan data deskriptif berupa kata-kata tertulis atau lisan dari orang-orang dan perilaku yang dapat diamati (Bogdan, R. dan Taylor, S.J. dalam Moleong, L.J., 2003:3). Metodenya adalah studi kasus, untuk meneliti secara terinci tentang seseorang atau sesuatu unit selama kurun waktu tertentu (Sevila C.G., et.al, (2003:73). Metode studi kasus ini digunakan dengan melibatkan diri lebih dalam menganalisis secara menyeluruh tentang perilaku individu yang berkaitan proses pelatihan kewirausahaan di PKBM Nurul Furqon. Penentuan subyek penelitian dilakukan dengan cara "purposive sampling" (sesuai dengan tujuan), dengan menentukan satu orang pengurus, satu orang pelatih dan empat orang warga belajar. Hal ini sesuai pendapat Nasution (1988:11) bahwa "Metode naturalistik tidak menggunakan sampling random atau acak, dan tidak pula menggunakan populasi atau sampel yang banyak". Sampel atau subyek penelitian biasanya sedikit dan dipilih berdasarkan tujuan (purposive) penelitian. Instrumen dalam penelitian ini adalah diri sendiri. Artinya, peneliti berperan sebagai observer as participant. Peneliti sebagai instrumen berupaya menerapkan rambu-rambu untuk memahami latar belakang penelitian, mempersiapkan diri, meyakini hubungan di lapangan dan melibatkan diri sambil mengumpulkan data (Moleong, L.J., 2003:102).

Teknik pengumpulan data menggunakan observasi, wawancara mendalam (indepth interview), dan dokumentasi sebagai sumber data triangulasi untuk mempertanggungjawabkan keakuratannya. Proses penelitian dilakukan dengan menginterpretasikan dan menganilis data secara terus menerus sejak awal hingga selesai penelitian. Tahap penelitian dilakukan melalui tiga tahapan, yaitu: 1) tahap orientasi untuk memperoleh data penting yang ditemukan, 2) tahap eksplorasi untuk menentukan fokus penelitian, dan 3) tahap member check untuk mengecek temuan hasil penelitian sesuai prosedur dan menyusun laporan akhir (Nasution, 1991:129). Adapun teknik analisis data hasil penelitian dilakukan menggunakan model interaktif, melalui langkah-langkah: 1) koleksi data (data collection), 2) penyederhanaan data (data reductional), 3) penyajian data (data display), dan 4) pengambilan kesimpulan, serta verifikasi (conclusion: drawing verying) (Miles, B.M. dan Huberman, M.A., 1994:20).

\section{HASIL PENELITIAN DAN PEMBAHASAN}

Dalam melaksanakan program pendidikan masyarakat, PKBM Nurul Furqon memiliki visi "Terwujudnya masyarakat yang berahlak mulia, berbudi pekerti luhur, cerdas, terampil, mandiri, berdaya saing dan gemar belajar. Dalam melaksanakan visinya PKBM Nurul Furqon memiliki misi: 1) mewujudkan program pendidikan nonformal dan informal, 2) berbasis pada masyarakat luas, 3) berorientasi pada keterampilan hidup (life skill), khusuanya usaha bidang konveksi, 4) memasyarakatkan program gemar belajar dan, 5) membelajarkan masyarakat.

\section{Identifikasi Kebutuhan Pelatihan Kewirausahaan}

Identifikasi kebutuhan pelatihan kewirausahaan di PKBM Nurul Furqon dikembangkan sesuai dengan kebutuhan belajar warga belajar. Secara umum kegiatan identifikasi kebutuhan 
pelatihan kewirausahaan berbasis kepada partisipasi masyarakat ini adalah sebagai proses pengumpulan data untuk dianalisis berbagai bidang usaha atau faktor-faktor yang ada di dalam pengembangan kewirausahaan yang perlu ditingkatkan atau diperbaiki agar produktivitas usaha PKBM Nurul Furqon meningkat.

Tujuan kegiatan identifikasi kebutuhan pelatihan kewirausahaan ini adalah memperoleh data yang akurat yang dirasakan masyarakat untuk menyelenggarakan pelatihan. Manfaat dari identifikasi kebutuhan ini adalah untuk; 1) memperoleh data tentang permasalahan yang dihadapi dan kebutuhan belajar yang dirasakan dan diperlukan warga belajar, 2) mempermudah penentuan prioritas dalam perencanaan pelatihan kewirausahaan, dan 3) memperlancar pelaksanaan pelatihan kewirausahaan. Tahap identifikasi kebutuhan program pengembangan kewirausahaan berbasis partisipasi masyarakat dilaksanakan melalui prosedur identifikasi kebutuhan belajar masyarakat, yaitu sebagai berikut;

a. Persiapan

1) Menentukan lokasi kelompok sasaran, dengan memperhatikan wilayah desa yang menjadi objek identifikasi,

2) Merumuskan dan menentukan data yang perlu diidentifikasi,

3) Menentukan teknik identifikasi,

4) Berkonsultasi dengan tokoh masyarakat sekitar,

5) Mempersiapkan instrument identifikasi,

6) Menentukan waktu pelaksanaan identifikasi.

b. Langkah-Langkah Pelaksanaan

1) Mengumpulkan warga masyarakat di tempat yang telah disepakati bersama, atau mengunjungi langsung warga masyarakat secara perorangan dirumah atau ditempat kerja masing-masing,

2) Memberikan penjelasan kepada warga masyarakat maksud dan tujuan kegiatan identifikasi,

3) Melakukan wawancara atau tanyajawab dengan warga masyarakat sebagai calon warga belajar,

4) Mengelompokkan data yang terkumpuln berdasarkan data jenis kelamin, usia, pendidikan, mata pencaharian kelompok sasaran,

5) Mengambil kesimpulan dari pengolahan data.

6) Penemuan ide proyek usaha

7) Pengembangan jenis usaha

8) Produk pengembangan usaha yang dibuat harus disetujui dan laku untuk dijual.

Pada tahap ini pengurus dan warga belajar di PKBM melakukan pengamatan terhadap kebutuhan pasar dan pengembangan jenis produk usaha konveksi (seperti kemeja, kaos, topi dan lain-lain). Pengamatan berbagai jenis produk usaha ini dilakukan sesuai kriteria-kriteria produk konveksi yang dibuat untuk memenuhi kebutuhan pasar. Produk tersebut dilaksanakan untuk memenuhi kebutuhan konsumen yang belum ada atau mengganti produk yang telah ada dengan produk yang memiliki nilai lebih. Sementara untuk kebutuhan pasar, hasil pengamatan yang diharapkan bahwa produk konveksi yang dihasilkan dapat dijual di pasar yang cukup sehat. Artinya permintaan terhadap produk itu cukup baik dalam jangka panjang. Selanjutnya, untuk mendapatkan ide usaha konveksi sebelumnya pengurus PKBM melakukan pengamatan pangsa pasar yang terorganisasi baik dengan sumberdaya yang ada dan memadai. Ide usaha konveksi yang diambil keputusannya tergantung pada tiga faktor, pertama adalah ide usaha konveksi yang sesuai; kedua, warga belajar mampu untuk melibatkan diri dalam mengerjakan 
hal-hal teknis; dan ketiga, keyakinan pada kemampuan dalam menghasilkan keuntungan/laba. Tahap pengembangan ide usaha koveksi ini satu atau lebih, tetapi pada keputusan dipilih atas keputusan bersama sesuai skala prioritasnya.

Seperti telah dijelaskan di atas, berdasarkan hasil identifikasi kebutuhan belajar, warga belajar dan pengurus PKBM menyepakati bahwa pengembangan proyek usaha yang dilaksanakan sesuai dengan potensi wilayah dan peluang pasar yaitu bidang konveksi. Identifikasi ini dilakukan pengurus PKBM melalui teknik survey dan wawancara mendalam kepada warga belajar. Teknik ini banyak digunakan dalam mengidentifikasi kebutuhan belajar. Seperti halnya penelitian Chanda, A. Dan Huesin, A. (2018) yang menyimpulkan bahwa identifikasi kebutuhan masyarakat telah dilakukan untuk mendeskripsikan kebutuhan masyarakat dalam pendirian Taman Bacaan Masyarakat di Desa Tanjung Seteko, Kecamatan Indralaya. Identifikasi dilakukan menggunakan Kartu Sistem Kebutuhan Belajar Masyarakat (SKBM) dan survey. Dengan teknik identifikasi kebutuhan belajar tersebut program pemberdayaan masyarakat melalui Taman Bacaan Masyarakat dapat memenuhi kebutuhan belajar masyarakat.

\section{Pelaksanaan Pelatihan Kewirausahaan}

Setelah mengembangkan dan menetapkan ide-ide proyek usaha yang disepakati pada tahap identifikasi kebutuhan belajar, selanjutnya dilakukan pelatihan kewirausahaan yang menggunakan pendekatan partisipatif dan beberapa metode pelatihan orang dewasa. Proses pelatihan kewirausahaan dibuat situasinya dilaksanakan seperti sedang berusaha konveksi yang sebenarnya. Tahap pelatihan kewirausahaan dilaksanakan bersamaan dengan berjalannya usaha konveksi warga belajar. Setelah semua persiapan, semua warga belajar menjalankan usaha konveksi, mulai dari ketua kelompok usaha bekerjasama dengan warga belajar sesuai rencana usaha konveksi yang ditetapkan. Dalam faktanya memang masih terdapat kesulitan dalam melaksanakan rencana usaha konveksi yang dibuat sama dengan realisasinya. Pada pelaksanaan pelatihan kewirausahaan di PKBM Nurul Furqon, warga belajar berpartisipasi secara aktif. Partisipasi warga belajar dalam pelaksanaan pelatihan kewirausahaan ini memberi peran yang sangat penting menentukan keberhasilan usahanya.

Pentingnya partisipasi warga belajar dalam kegiatan pendidikan masyarakat ini sejalan dengan hasil penelitian Dwiyanto, B.M. (2011) yang menyimpulkan bahwa model peningkatan partisipasi masyarakat dalam pengelolaan sampah perkotaan, khususnya sampah rumah-tangga di Kelurahan Sambiroto, Kecamatan Tembalang, Kota Semarang. Pendekatan model pengelolaan sampah terpadu berbasis masyarakat ini menggunakan pendekatan pemberdayaan masyarakat (community empowering) melalui peningkatan pastisipasi stakeholdersnya. Hasil penelitian lainnya menunjukkan bahwa partisipasi masyarakat lokal dilakukan dengan mendesain sendiri model pariwisata yang dikembangkan di Desa Jatiluwih Tabanan Bali. Pengembangan desa wisata berjalan sesuai dengan kebutuhan masyarakat karena adanya jaminan partisipasi masyarakat di dalamnya. Pihak pemerintah mengurangi peranannya dalam pengembangan desa wisata dan memberikan peranan yang lebih besar kepada masyarakat untuk berpartisipasi (Dewi, H.U., dkk, 2013).

Pelatihan kewirausahaan dan pengembangan usaha konveksi di PKBM Nurul Furqun merupakan proses pembentukan wirausahawan-wirausahawan baru di masyarakat. Warga belajar dilatih untuk menjadi wirausahawan sebagai potensi pembangunan ekonomi kerakyatan. Pengembangan ekonomi kerakyatan ini akan lebih berhasil jika ditunjang wirausahawan baru yang dapat membuka peluang kerja bagi dirinya. Keberanian pembentukan sikap kewirausahaan bagi warga belajar ini dilaksanakan dengan memberikan pelatihan 
kewirausahaan yang praktis dan menarik dan dapat membangkitkan minat warga belajar untuk berwirausaha sesuai dengan kemampuannya. Hal ini sejalan dengan pendapat William B.W. Jr. dan Davis, K. (1986: 282) pelatihan dilaksanakan untuk meningkatkan sikap, perilaku, pengetahuan dan keterampilan tertentu dalam melakukan pekerjaannya. Pelatihan kewirausahaan di perusahaan misalnya, dilaksanakan untuk membantu karyawan melakukan pekerjaannya. Manfaat pelatihan di PKBM Nurul Furqun bertujuan mengembangkan kemampuan berwirausaha warga belajar untuk bertanggungjawab secara baik di masa depan dalam memenuhi kehidupan pribadi dan keluarganya. Pelatihan kewirausahaan ini merupakan proses dan hasil kedisiplinan yang sistematis dalam menerapkan kreativitas dan keinovasian warga belajar PKBM Nurul Furqon dalam mengembangkan usaha konveksi dengan mencari peluang pasar untuk memenuhi kebutuhan hidupnya (Zimmerer, T.W., 1996).

\section{Hasil Pelatihan Kewirausahaan}

Pada pelatihan kewirausahaan di PKBM Nurul Furqon dilakukan penilaian terhadap usaha konveksi yang didirikan (sering diistilahkan dengan penilaian proyek). Penilaian dilakukan dengan membandingkan sebelum dan setelah warga belajar menjalankan usaha. Tahap penilaian usaha konveksi dilakukan melalui tiga macam penilaian pelatihan kewirausahaan. Pertama, disetujuinya usaha konveksi yang didirikan dan dijalankan warga belajar. Kedua, pemilihan jenis usaha konveksi yang dijalankan warga belajar. Ketiga, mempelajari proyek usaha baru yang selesai dijalankan warga belajar. Penilaian dilakukan menggunakan lebih dari satu standar atau kriteria sesuai kesepakatan bersama. Standar atau kriteria tersebut dapat mempengaruhi hasil pelatihan kewirausahaan baik secara kuantitatif atau kualitatif. Penilaian dilakukan dengan membandingkan seluruh modal atau biaya usaha yang dikeluarkan serta hasil, manfaat dan keuntungan usaha yang telah dilaksanakan dan diperoleh. Sudah tentu, jenis usaha yang diprioritaskan memiliki nilai usaha tertinggi dibandingkan dengan proyek usaha yang disediakan berdasarkan kriteria-kriteria yang ada. Setelah suatu proyek usaha terpilih untuk dilaksanakan, dibuatkan rencana kerja pengembangan proyek usaha itu sendiri. Mulai dari menentukan jenis usaha, waktu yang diperlukan dari setiap jenis usaha, jumlah dan kualifikasi pelaksana usaha, modal/dana dan sumberdaya lainnya yang diperlukan untuk pengembangan usaha, kesiapan manajemen usaha dan lain-lain.

Hasil penilaian pelatihan kewirausahaan diharapkan memberikan dampak terhadap kemandirian berwirausaha bagi warga belajar di PKBM Nurul Furqon. Warga belajar dapat memberdayakan dirinya untuk memenuhi kebutuhan hidupnya, bahkan jika mungkin masyarakat di sekitarnya. Pemberdayaan masyarakat ini sebagai sebuah konsep pembangunan ekonomi yang memiliki nilai-nilai sosial. Konsep ini mencerminkan paradigma baru pembangunan, yang bersifat berpusat pada masyarakat, partisipasi masyarakat, pemberdayaan masyarakat, dan berkesinambungan (Chambers, R., 1995). Hasil pelatihan kewirausahaan diharapkan dapat melahirkan warga belajar menjadi wirausahawan baru yang mampu membuka sistem ekonomi yang ada dengan memperkenalkan barang dan jasa yang baru, dengan menciptakan bentuk dan jenis produksi konveksi yang baru atau mengolah bahan baku baru sesuai dengan perkembangan fashion masa kini. Hal ini sejalan dengan pendapat Schumpeter dalam Bygrave (1994: 1) yang menyatakan entrepreneur as the person who destroys the existing economic order by introducing new product and services, by creating new form of organization, or by exploiting new raw materials. 


\section{KESIMPULAN}

Tujuan identifikasi pelatihan kewirausahaan di PKBM Nurul Furqon adalah untuk mendapatkan data yang akurat tentang kebutuhan belajar yang dirasakan dan dibutuhkan masyarakat. Teknik identifikasi kebutuhan pelatihan kewirausahaan digunakan untuk; memperoleh data permasalahan yang dihadapi dan menentukan kebutuhan warga belajar sebagai sasaran, mempermudah dalam merumuskan, menyusun perencanaan pelatihan kewirausahaan, dan mempermudah dan memperlancar proses pelatihan kewirausahaan. Pada tahap pelaksanaan pelatihan, semua warga belajar menjalankan proyek usaha, mulai dari ketua kelompok usaha bekerjasama dengan warga belajar sesuai rencana proyek usaha yang ditetapkan. Pelatihan kewirausahaan dilaksanakan dengan menggunakan metode pelatihan orang dewasa. Proses pelatihan kewirausahaan dibuat situasinya seperti berusaha yang sebenarnya secara bersamaan dengan proyek usaha yang sedang dijalankan. Penilaian dilakukan dengan membandingkan sebelum dan setelah proses pelatihan kewirausahaan. Semua pihak menilai seluruh modal atau biaya usaha yang dikeluarkan dengan hasil, manfaat, dan keuntungan usaha yang telah diperoleh. Jenis usaha yang dianggap berhasil diprioritaskan yang memiliki nilai usaha tertinggi dibandingkan dengan proyek usaha yang disediakan sesuai dengan kriteria-kriteria yang ada. Setelah suatu proyek usaha dipilih untuk dilaksanakan, selanjutnya dibuat perencanaan usaha pengembangan proyek usaha untuk kemajuan usaha di masa yang akan datang.

\section{DAFTAR PUSTAKA}

Bogdan, R. dan Taylor, S. J. (1993). Dasar-Dasar Penelitian Kualitatif. Surabaya: Usaha Nasional.

Bygrave, W.D. (1994). The Portable MBA in Entrepreneurship. John Willey \& Sons, Inc. New York.

Candra, A. dan Husein, A. (2018). Identifikasi Kebutuhan Masyarakat Terhadap Pendirian Taman Bacaan Masyarakat di Desa Tanjung Seteko Kecamatan Indralaya. Journal of Nonformal Education and Community Empowerment, vol. 2 (2), Desember 2018, hal. 93-99.

Cascio, W.F. (1995). Managing Human Resources: Productivity, Quality of Work Life. McGraw-hill Inc. USA.

Chambers, R. (1985). Rural Development: Putting the Last First. London: New York: Longman.

Dewi, H.U. dkk. (2013). Pengembangan desa wisata berbasis partisipasi Masyarakat lokal di Desa Wisata Jatiluwih, Tabanan Bali. Jurnal Kawistara, vol. 3 (2), 17 Agustus 2013, hal. 117-226.

Drucker, P.F. (1994) Innovation and Entrepreneurship, Practice and Principle. New York: Harper Business.

Dwiyanto, B.M. (2011). Model Peningkatan Partisipasi Masyarakat dan Penguatan Sinergi Dalam Pengelolaan Sampah Perkotaan. Jurnal Ekonomi Pembangunan, vol. 12 (2), Desember 2011, hlm. 239-256.

Flippo, E. B. (1994). Principles of Personal Management. New York: McGraw-Hill Book Company Inc. 
Meredith, Geoffrey, G. et.al. (1996). Kewirausahaan Teori Dan Praktek. Jakarta: PT. Pustaka Binaman Presindo.

Miles, B.M. dan Huberman, M.A. (1992). Analisis Data Kualitatif. Jakarta: UI Press.

Moleong, L. J. (1988). Metode Penelitian Kualitatif. Bandung: Remaja Rosdakarya.

Nasution (1996). Metode Penelitian Naturalistik Kualitatif. Bandung: Tarsito.

Rappaport, J. (1984). Studies in empowerment: Introduction to the issue. Prevention in Human Services, 3, 1-7.

Rosyida, I. dan Nasdian, F.T. (2011) Partisipasi Masyarakat dan Stakeholder Dalam Penyelenggaraan Program Corporate Social Responsibility (CSR) dan Dampaknya Terhadap Komunitas Perdesaan. Sodality: Jurnal Transdisiplin Sosiologi, Komunikasi, dan Ekologi Manusia, vol. 5(1), April 2011, hlm. 51-70.

Sevila C.G. et al. (2003). Pengantar Metode Penelitian. Jakarta: UI Press.

Soeparman, S. (1980). Membina Sikap Mental Wirausaha. Jakarta: Gunungjati.

Suharto, E. (2004). Modal Sosial dan Kebijakan Publik. pdf (secured). 23/6/2007. 1:49PM.

Syahid,. A. (2017) Teknik Identifikasi Program Paket C dalam MeningkatkanKeterampilan Fungsional Warga Belajar. Journal of Nonformal Education and Community Empowerment, vol. 1(1): Juni 2017, hal. 18-31.

Swift, C. and Levin, G. (1987). Empowerment: An Emerging Mental Healt Technology. J. Primary Prevention, USA.

Usman, M. (1997). Keuangan dan Perbankan Indonesia. Jakarta: Pinandita Press.

William B.W. Jr. and Davis, K. (1996). Human Resources and Personnel Management. New York: McGraw-Hill.

Hermawan, Y. dan Suryono, Y. (2016). Partisipasi Masyarakat Dalam Penyelenggaraan Program-Program Pusat Kegiatan Belajar Masyarakat Ngudi Kapinteran. Jurnal Pendidikan dan Pemberdayaan Masyarakat, vol. 3(1), Maret 2016, hal. 97-108. 